\title{
Review of the Structural and Functional Brain Changes Associated With Chronic Kidney Disease
}

\author{
Martin MICHNA ${ }^{1}$, Lucie KOVAROVA ${ }^{2}$, Anna VALERIANOVA ${ }^{2}$, Hana MALIKOVA ${ }^{1}$, Jiri \\ WEICHET $^{1}$, Jan MALIK ${ }^{2}$ \\ ${ }^{1}$ Department of Radiology, University Hospital Kralovske Vinohrady and Third Faculty of \\ Medicine, Charles University, Prague, Czech Republic, ${ }^{2}$ Third Department of Internal Medicine, \\ General University Hospital and First Faculty of Medicine, Charles University, Prague, Czech \\ Republic
}

Received December 15, 2019

Accepted August 4, 2020

Epub Ahead of Print November 2, 2020

\begin{abstract}
Summary
Chronic kidney disease (CKD) leads to profound metabolic and hemodynamic changes, which damage other organs, such as heart and brain. The brain abnormalities and cognitive deficit progress with the severity of the CKD and are mostly expressed among hemodialysis patients. They have great socio-economic impact. In this review, we present the current knowledge of involved mechanisms.
\end{abstract}

\section{Key words}

Structural brain changes $\bullet$ Cognitive impairment $\bullet$ Hemodialysis

\section{Corresponding author}

Martin Michna, Srobarova 50, 10034 Praha 10, Czech Republic. E-mail: martin.michna@fnkv.cz

\section{Introduction}

"Insidious" is an adjective that in a simple way describes many complications of chronic kidney disease (CKD). CKD leads to profound metabolic and hemodynamic changes, that damage other organs, such as heart and brain. CKD is defined as a decreased kidney function shown by glomerular filtration rate of less than $60 \mathrm{ml} / \mathrm{min}$ per $1.73 \mathrm{~m}^{2}$, or markers of kidney damage, or both, of at least 3-month duration (Webster et al. 2017).

$\mathrm{CKD}$ is an emerging problem. In Europe, it affects between $3.3 \%$ and $17.3 \%$ (Bruck et al. 2016) and its prevalence tends to increase (Hill et al. 2016). This occurs especially due to increased prevalence of two main causes of renal failure: diabetes mellitus and arterial hypertension (Jha et al. 2013). The progression of the disease is slow, but gradual decline of the kidney function can lead to renal failure and necessity to initiate renal replacement therapy.

Cardiovascular and neurological CKD complications bring most morbidity and mortality. Stroke is the second leading cause of death worldwide (Masson et al. 2015). Among the CKD patients its incidence is 5-30 times higher (Nayak-Rao and Shenoy 2017) than in non-CKD population and is strongly associated with higher prevalence of atrial fibrillation, especially after the initiation of dialysis (Reinecke et al. 2009). Also, as the glomerular filtration declines, the kidneys are unable to eliminate all uremic metabolites. Retention of neurotoxins leads to neuronal damage and to uremic encephalopathy (Bugnicourt et al. 2013). The symptoms range from mild cognitive impairment to severe symptoms such as seizures and coma (McQuillan and Jassal 2010).

Uremic toxins, anemia, oxidative stress, inflammation and hyperhomocysteinemia are the nontraditional cardiovascular risk factors specific to CKD. They contribute to vascular injury along with traditional cardiovascular risk factors such as arterial hypertension, smoking and diabetes (Brouns and De Deyn 2004, 
Malyszko 2010), causing endothelial dysfunction and thus acceleration of atherosclerosis (Arnold et al. 2016, Malyszko 2010) that affects also cerebral arteries. These risk factors play a significant role in the development of dementia (Arnold et al. 2016). Cognitive impairment of any level affects up to $80 \%$ of CKD patients (Krishnan and Kiernan 2009). As the cognition worsens, the quality of patient's and his/her relatives' lives decline and mortality increases (Griva et al. 2010). Socioeconomic impact of central nervous system (CNS) impairment is profound.

In end stage renal disease (ESRD), renal replacement therapy is necessary for survival. Hemodialysis (HD) is the most frequent method. On the other hand, HD per se has many effects on the CNS. The dialysis disequilibrium syndrome is one of the most menacing and still poorly understood condition (ZepedaOrozco and Quigley 2012). Prevalence of dementia among HD patients is more than three times higher than in non-dialysis population aged $\geq 65$ years (Murray et al. 2006). Cognitive impairment is positively correlated with HD duration (and also positively correlated with age of the patient and negatively correlated with years of education as in the general population) (Gesualdo et al. 2017). Although many mechanisms have probably not been revealed, the presence of ESRD and the hemodialysis therapy itself have strong detrimental effects on the brain (Etgen et al. 2012). These effects often prevail over other mechanisms, such as hypertension or diabetes mellitus.

The etiology of CNS changes in CKD patients is complex and the understanding of them is the first step in their prevention and therapy. The aim of this manuscript is to review known mechanisms and methods necessary for understanding these changes, their causes, and their impact.

\section{Cognitive impairment}

\section{General population}

By definition, cognitive impairment is present when there is evidence of decline in one or more of the following domains: memory, executive functioning, attention, speed of information processing, perceptual motor ability, or language (Van Sandwijk et al. 2016). Some degree of cognitive slowing is, however, typical of normal aging. Dementia is diagnosed when acquired cognitive impairment has become severe enough to compromise social and/or occupational functioning. The most common types of dementia are Alzheimer's disease, vascular dementia, Lewy body dementia and frontotemporal dementia. These conditions and others, such as Parkinson's disease, Huntington's disease, Creutzfeldt-Jakob's disease, and Pick's disease lead to progressive irreversible dementia. Among conditions which can lead to reversible dementia are brain tumors, head injuries, metabolic changes, nutritional deficiencies, chronic alcohol abuse and many others (Tripathi and Vibha 2009). Mild cognitive impairment (MCI) is an intermediate state between normal cognition and dementia, with essentially preserved functional abilities (Hugo and Ganguli 2014).

Prevalence of dementia increases exponentially with increasing age, and doubles with every five years of age after the age of 65 . In higher income countries, its prevalence is $5-10 \%$ in patients aged 65 years and more and affects more frequently women than men. The prevalence of MCI is at this point difficult to determine as it depends on the precise definitions and subtypes of MCI being studied (Hugo and Ganguli 2014).

To diagnose these entities, clinicians use a standardized framework such as the fifth edition of the American Psychiatric Association's Diagnostic and Statistical Manual (DSM-5). In accordance with the terminology of DSM-5, Major Neurocognitive Disorder corresponds to dementia and Mild Neurocognitive Disorder corresponds to MCI. The substantial (in the case of dementia) or modest (in the case of MCI) impairment should be both observed by clinician or a reliable informant and documented by objective cognitive assessment (Association 2013).

The worldwide number of persons affected by dementia and MCI is increasing (Fratiglioni and Qiu 2011). In contrast to dementia, MCI does not interfere notably with activities of daily life, but its diagnosis permits early identification of high-risk patients. This opens a potentially larger therapeutic window and increases the significance of identification, diagnosis and treatment of modifiable risk factors (Fratiglioni and Qiu 2011). CKD is one of them.

\section{Chronic kidney disease}

CKD appears to be a significant and independent somatic risk factor for the development of cognitive decline. The prevalence of MCI is estimated to be 7-26\% in general population. The prevalence of MCI in patients with advanced CKD (stages 4 and 5) is 16-38\% (Viggiano et al. 2020). Hemodialysis patients have even 
higher prevalence of MCI: "26-60\%" (Viggiano et al. 2020).

A meta-analysis comprising 54,779 participants revealed increased risk of MCI with the gradual decreasing estimated glomerular filtration rate (eGFR), i.e. with the severity of CKD (Etgen et al. 2012). In general, pre-dialysis and pre-transplant occurrence of cognitive deficit is relatively modest in well cared for, dementia- and stroke-free community samples (Elias et al. 2013), but among patients that reach ESRD, the rates of dementia are already approximately three times higher than in age-matched general population (Tamura and Yaffe 2011).

\section{Renal replacement methods}

Renal replacement methods include HD, peritoneal dialysis (PD) and kidney transplantation. HD is most frequent. Up to $70 \%$ of HD patients aged 55 and older suffer from moderate to severe chronic cognitive impairment (Murray 2008). Cognitive decline is faster in HD patients compared to non-dialysis patients with advanced CKD. Cognitive functions also deteriorate faster in HD patients compared to PD patients. (Iyasere et al. 2017). Why is the cognitive impairment the greatest in patients treated with HD?

One explanation is in the levels of the uremic toxins, small molecules, which concentrations rise with decreasing kidney function. Indoxyl-sulfate, p-cresyl sulfate, asymmetric and symmetric dimethylarginine (SDMA, ADMA) and trimethylamine N-oxide (TMAO) are examples (Stubbs et al. 2016, Oliva-Damaso et al. 2019, Dobrian 2012, Liu et al. 2018c). The blood concentration of asymmetric dimethylarginine (ADMA, a small water-soluble uremic toxin) was increased in CKD patients approximately 2 to 8 -fold, more in HD than in PD patients (Vanholder et al. 2003). ADMA is an endogenous inhibitor of nitric oxide synthase, so its increased levels lead to endothelial dysfunction. Higher serum levels of another toxin, indol-3 acetic acid, were associated with cognitive impairment (Lin et al. 2019). The small uremic toxins could easily cross the bloodbrain barrier and their increased serum levels would probably drive such crossing.

Modern HD provides better clearance of large solutes and protein-bound solutes than PD (Meyer and Hostetter 2014). However, the plasma levels of proteinbound uremic toxins were lower in PD patients compared to HD patients (Lameire et al. 2001, Vanholder et al. 2009). The plasma concentration of glycation free adducts is increased 18-fold in PD patients and 40-fold in HD patients (Lisowska-Myjak 2014). This might be explained due to better residual kidney function among PD patients (Pham et al. 2008, Lee et al. 2010a). Other possible explanation is in the change of the intestinal microbiome in HD patients and increased production of toxins (Vanholder et al. 2009).

Additional possible mechanism, by which conventional HD can contribute to cognitive decline, is intradialytic hypotension that affects especially anuric patients and subjects with increased arterial stiffness and heart failure (Malik 2018). The changes of blood pressure can cause episodes of acute cerebral ischemia. However, blood pressure per se is a poor predictor of cerebral ischemia. This is because of variable lower limits of cerebral autoregulation and varying ability to increase oxygen extraction (MacEwen et al. 2017).

Hemodialysis sessions also bring the risk of states of acute cognitive decline - i.e. delirium, which, although reversible, often have a negative impact on long-term cognitive performance (Murray 2008). The cause of delirium is probably due to electrolyte disbalances, that occur during dialysis (Yasui-Furukori et al. 2017).

Cognitive performance improves after kidney transplantation (Gupta et al. 2016, Findlay et al. 2019, Joshee et al. 2018). However, cognition of these posttransplanted patients remains worse when compared to a healthy group. Some of the cognitive functions such as attention, executive functions, verbal fluency and language do not improve at all (Joshee et al. 2018).

\section{Cerebral oxygenation and blood flow}

\section{Determinants and measurement of cerebral oxygenation} and cerebral blood flow

The brain has a remarkably high metabolic rate it utilizes approximately $50 \mathrm{ml}$ of oxygen per minute, which equals $20 \%$ of the total oxygen consumption of the human body at rest. Most of the energy is used for maintaining the ion homeostasis with sodium-potassium ATPase, proteosynthesis and synthesis of neurotransmitters. The brain, therefore, depends on aerobic metabolism and on glucose and oxygen supply. This makes it very vulnerable to hypoxia, and the metabolic demand of the tissue is one of the factors that affect the cerebral blood flow (CBF). The main determinants of cerebral oxygenation ( $\mathrm{crSO} 2)$ are arterial oxygen concentration, blood oxygen carrying capacity 
(hemoglobin concentration), cerebral blood flow and cerebral oxygen consumption. Traditional determinants of cerebral energy metabolism are cerebral metabolic rate of oxygen (CMRO2), $\mathrm{CBF}$ and venous blood oxygenation (Catchlove et al. 2018). A novel method of measuring brain tissue oxygenation is near-infrared spectroscopy (NIRS). It employs a non-invasive transcutaneous approach. The resulting value, regional oxygen saturation (rSO2), combines venous, arterial, and microcirculatory oxygen saturation. This method is widely used for monitoring in intensive care units or during anesthesia (Moerman and Wouters 2010).

\section{General population}

CBF is about $50 \mathrm{ml} / 100 \mathrm{~g} / \mathrm{min}$ at birth, peaks around the age of 5 with average value of $70 \mathrm{ml} /$ $100 \mathrm{~g} / \mathrm{min}$ (Tasker 2013). Then CBF slowly decreases to the normal average adult value of $50 \mathrm{ml} / 100 \mathrm{~g} / \mathrm{min}$, reaching it at around 19 years of age (Lassen 1985, Tasker 2013). The average CBF of the white matter is approximately $20 \mathrm{ml} / 100 \mathrm{~g} / \mathrm{min}$, perfusion of the grey matter is higher, about $80 \mathrm{ml} / 100 \mathrm{~g} / \mathrm{min}$ (Vavilala et al. 2002). During healthy aging the CBF progressively decreases, mainly in cortical regions (Chen et al. 2011). Decreased brain metabolism (Leenders et al. 1990), elevation of the blood pressure (Tarumi and Zhang 2018) and/or pathologic changes of brain vessels could be the underlying causes (Wagner et al. 2012).

A recent study (Catchlove et al. 2018) reported higher oxygen extraction rate in older subjects with no age-dependent change in $\mathrm{CMRO} 2$, this finding suggests that there is certain disproportion between oxygen demands and supply in the brain in elderly population

\section{Chronic kidney disease}

Recent studies have shown that patients with CKD have significantly lower cerebral oxygenation when measured by the non-invasive near-infrared spectroscopy
(NIRS) (Malik et al. 2016, Prohovnik et al. 2007, Ito et al. 2015, Hoshino et al. 2014) than the healthy population, the results are summarized in Table 1. Patients treated with HD have even lower regional oxygen saturation (rSO2) than patients treated with PD (Papadopoulos et al. 2013). There is no significant difference in rSO2 before vs. after hemodialysis session (Hoshino et al. 2014, Valerianova et al. 2019). However, brain oxygenation is not stable during hemodialysis, our previous study showed that $\mathrm{rSO} 2$ values drop after the beginning of hemodialysis and reach their minimum in 35th minute (Malik et al. 2016). Furthermore, CBF can decline by $10-15 \%$ during hemodialysis cycle (PolinderBos et al. 2018). These hemodynamic changes occurring during fast fluid removal could be responsible for brain hypoxia (Malik et al. 2016) and participate on cognitive decline.

Lower $\mathrm{rSO}_{2}$ is independently associated with higher $\mathrm{pH}$, longer HD duration and lower serum albumin concentration, $\mathrm{rSO} 2$ is also lower in patients with diabetes mellitus (Ito et al. 2015) and heart failure (Valerianova et al. 2019). Decrease of $\mathrm{pH}$ induces dilation of cerebral arteries (Kontos et al. 1977) resulting in cerebral blood flow increase. The association of $\mathrm{rSO}_{2}$ with changes of $\mathrm{pH}$ could thus be explained by changes in oxygen delivery (Ito et al. 2015).

Prohovnik et al. (2007) reported lower rSO2 and lower cerebral blood flow in ESRD patients before HD. $\mathrm{CBF}$ declined to $60 \%$ of its normal level during interdialytic interval and was once again restored by HD procedure. The recent study demonstrated that lower eGFR was associated with lower CBF (Sedaghat et al. 2016). This could be due to impaired cerebral autoregulation and/or accumulation of vasoactive substances, such as ADMA, what can lead to vasoconstriction of cerebral vessels (Sedaghat et al. 2016, Zoccali et al. 2002).

Table 1. Results of the cerebral oxygenation in chronic kidney disease patients, measured by NIRS.

\begin{tabular}{lccccc}
\hline Author & Year & Patients & ESRD group & Control group & p-value \\
\hline Ito et al. & 2015 & 54 & $50 \pm 2 \%$ & $69 \pm 2 \%$ & $<0.001$ \\
Hoshino et al. & 2014 & 18 & $56 \pm 1 \%$ & $70 \pm 3 \%$ & $<0.001$ \\
Malik et al. & 2016 & 27 & $52 \pm 11 \%$ & $68 \pm 7 \%$ & $<0.0001$ \\
Prohovnik et al. & 2007 & 7 & $41 \pm 13 \%$ & $70 \pm 2 \%$ & $<0.01$ \\
\hline
\end{tabular}


Nonetheless, not all studies are in accordance with these observations. Some observed increased and not decreased CBF in CKD patients, both in non-dialysis (Jiang et al. 2016, Tamura et al. 2016) and in those undergoing the dialysis treatment (Vorstrup et al. 1992, Mathew et al. 1985, Jiang et al. 2016, Cheng et al. 2019). Increased CBF is most likely the result of decreased oxygen carrying capacity of the blood due to anemia (Liu et al. 2018b). This explanation is supported by CBF correction after anemia treatment (Hirakata et al. 1992). Other possible explanation includes impaired cerebrovascular autoregulation (Tamura et al. 2016). Alternatively, the brain "overperfusion" could be just a presentation of hyperkinetic circulation typical for CKD patients because of water retention, anemia and arteriovenous access (Malik 2018).

Both cerebral hypoperfusion and hyperperfusion could contribute to brain damage. The former can cause ischemia and the latter can be involved in the disruption of the blood brain barrier (BBB) and subsequent white matter (WM) degeneration (Mansour et al. 2019).

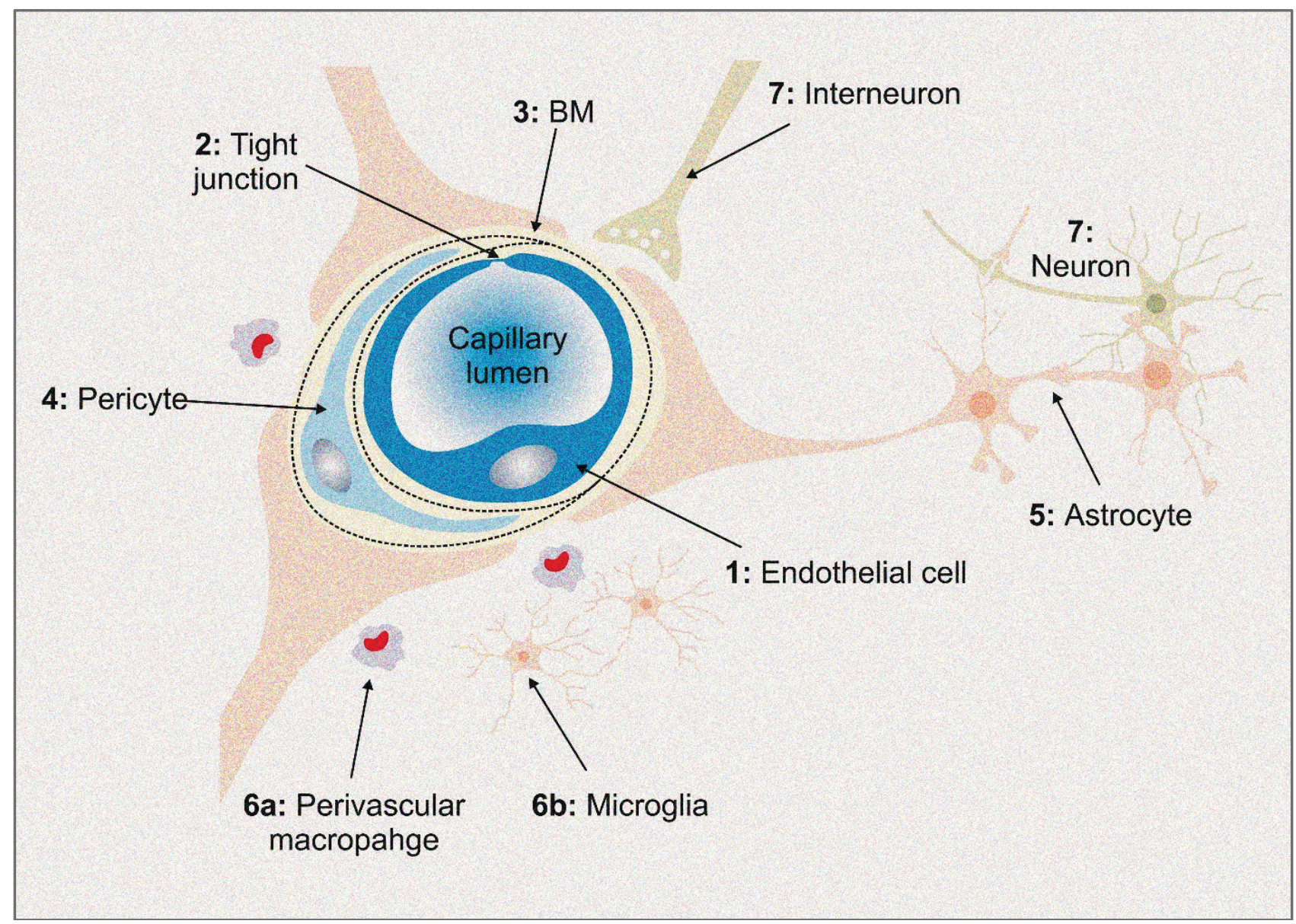

Fig. 1. Perivascular Macrophage

1. Endothelial cells (EC) regulate the movement of the molecules, ions and cells through the BBB. 2. Tight junctions of the $E C$ limit the paracellular movement (passive diffusion) and cause polarization of the EC, what is necessary for the molecular transport in a polarized manner. 3. Vascular basement membrane provides additional barrier, maintains the integration of the endothelial cells with pericytes and astrocytes. Also, vascular basement membrane ensures cell-cell and cell-matrix interactions. 4. Pericytes participate in the formation of the BBB during embryogenesis. Their contractive ability allows them to regulate blood flow at the capillary level. Other functions are: regulation of an angiogenesis, vascular stability, stem cell like activity and macrophage-like phagocytosis. 5. Astrocytes coordinates cerebral blood flow. Also, the astrocytes have many functions related to the maintenance of the neural microenviroment, such as the management of the extracellular $\mathrm{pH}$, water transport, osmotic balance and antioxidant system. 6. Immune cells have two main populations in the CNS. Perivascular macrophages serve as phagocytes, providing first line immunity. Microglial cells, besides phagocytosis, participate in pro-inflammatory response as well as in the neurotrophic pathways. 7. Neurons detect altered concentrations of the oxygen and nutrients. Neurons transmit signal to vessels through interneurons and astrocytes, influencing the vascular response depending on supply requirements. 


\section{Blood brain barrier}

\section{Physiology of the blood brain barrier}

The human brain weighs approximately $2 \%$ of the body mass, but receives $12-15 \%$ of the cardiac output at rest (Williams and Leggett 1989). This disproportion demonstrates that the brain is a highly perfused organ, immensely dependent on the supply of nutrients and oxygen. The function of the blood brain barrier (BBB) (Fig. 1) is to maintain the CNS microenvironment stable and to prevent the entry of neurotoxic metabolites, blood cells and pathogens (Daneman and Prat 2015).

The BBB is formed by the endothelial cells, pericytes, astrocyte end-feet, interneurons and immune cells. Endothelial cells are the core component. They possess specific attributes that ensure BBB integrity and homeostasis. Unlike other parts of the human body, the capillaries here are non-fenestrated and the adjacent cells are sealed together by protein complexes forming the tight junctions (Fig. 1). Endothelial cells have low pinocytic activity, which significantly reduces the vesicle-mediated transcellular passage of the molecules through the BBB (Engelhardt and Liebner 2014). However, endothelial cells possess high amount of specific transporters that regulate the transcellular influx of nutrients and ensure the efflux of waste products (Stamatovic et al. 2008). Higher concentration of mitochondria within endothelial cells provides energy for transporters and the maintaining of CNS homeostasis (Daneman and Prat 2015).

The extraluminal surface of the endothelial cells is surrounded by a vascular basement membrane. It is an extracellular network of proteins secreted by the endothelial cells, pericytes and astrocytes (Hallmann et al. 2005, Daneman and Prat 2015). Pericytes (Fig.1), embedded in the basement membrane, are cells that incompletely cover the abluminal surface of the blood vessels. They communicate with adjacent cells by both direct physical contact and paracrine signaling, and thus they participate in BBB regulation (Liu et al. 2012).

Astrocytes (Fig. 1) represent the supporting cells of the CNS. These specialized glial cells have foot-like extensions of their cell membranes, called end-feet. The end-feet ensheath both the endothelial cells and the neuronal processes. Therefore, astrocytes serve as a "bridge", physically and functionally connecting the neurons and vessels (Liu et al. 2018a).

These structures, along with neurons, interneurons and immune cells (microglia and perivascular macrophages), form a dynamic multicellular structure called the neurovascular unit (Sharif et al. 2018) (Fig. 1). The complex interaction within results in a highly effective system, essential for the normal function of the brain (Netto et al. 2018). Disruption of the neurovascular unit on any level could have direct consequences on neuronal functions (Keaney and Campbell 2015). Disruption of the BBB is associated with numerous diseases, such as ischemic stroke, epilepsy and neurodegenerative disorders (Palmer 2010, Obermeier et al. 2013).

\section{Chronic kidney disease and blood brain barrier}

The data about the association of BBB disruption and CKD is limited.

Mice model of CKD was developed to study BBB integrity and behavioral abnormalities (Mazumder et al. 2016). Albumin-bound Evans blue was administered to the mice circulation and later observed in the brain parenchyma due to BBB disruption. Moreover, the mice with CKD presented psychomotor and behavioral abnormalities. Other animal model study showed erosion of the tight-junction proteins among uremic CKD rats (Jing et al. 2018). Urea in concentration like in dialysis patients damaged the actin cytoskeleton and decreased expression of claudin-5 (protein of tight junctions) (Lau et al. 2020).

However, uremia is not the only factor that can damage BBB. Various CKD-associated comorbidities causing systemic inflammation (such as arterial hypertension, type 2 diabetes, dyslipidemia) and chronic cerebral hypoperfusion can be involved in the process (Varatharaj and Galea 2017, Setiadi et al. 2018, Malkiewicz et al. 2019, Ueno et al. 2002). Increased permeability of the $\mathrm{BBB}$ allows infiltration of noxious agents, cytokines and immune cells into CNS (Jabbari and Vaziri 2018, Malkiewicz et al. 2019) what can contribute to neuroinflammation. Dysfunction of the neurovascular unit could impair CBF autoregulation, lead to reduction in CBF and cause ischemic injury (Iadecola 2017). Jin M. et al. (2020) reported neurovascular coupling impairments in HD patients. Furthermore, dysfunction of the neurovascular unit can decrease production of trophic factors by neurovascular unit cells and alter clearance of neurotoxic molecules and some proteins, such as $\beta$ amyloid and tau protein (Iadecola 2017).

Accumulated uremic toxins in the brain inhibit brain-blood efflux transporter (Organic anion 
transporter 3). This transporter provides efflux of indoxyl sulfate (possibly some other uremic toxins such as: hippuric acid and 3-Carboxy-4-methyl-5-propyl-2furanpropionate, indoleacetate) and neurotransmitter metabolites (Ohtsuki et al. 2002, Deguchi et al. 2006). The cerebrospinal fluid-blood efflux transporter (Organic cation transporter 3) is also inhibited by increased concentrations of uremic toxins in brain. This transporter provides efflux of creatinine (Hosoya and Tachikawa 2011).

Some guanidino compounds can activate glutamatergic pathways and are involved in GABAergic inhibition (De Deyn et al. 2001). This pathological process, excitotoxicity, can lead to nerve cell death. Indoxyl sulfate induces oxidative stress and inflammatory mediators in glial cells. Indoxyl sulfate also alters function of glial cells (astrocytes and mixed glial cells) and increases production of various cytokines and proinflammatory enzymes with toxic effect on CNS (Adesso et al. 2017). Methylguanidine contributes to neurodegeneration most likely via alteration in mitochondrial calcium homeostasis and pro-apoptotic effect of $\mathrm{H} 2 \mathrm{O} 2$ in astrocytes (Marzocco et al. 2010). Quinolinic acid (uremic toxin and brain endogenous excitotoxin) is a neurotoxin, proinflammatory mediator and alters the BBB integrity (Ting et al. 2009, Guillemin 2012). Moreover, quinolinic acid is a gliotoxin and can induce astrocyte apoptosis via excessive stimulation of N-methyl-D-aspartate receptors (NMDARs) (Lee et al. $2010 \mathrm{~b}$ ). The increase of neurotransmitter metabolites in the brain impairs metabolism of neurotransmitters and causes accumulation of neurotoxic intermediate metabolites (Ohtsuki et al. 2002).

The deficits in cholinergic function is associated with cognitive decline. In a recent study, the activity of the acetylcholinesterase was globally reduced in the brain of the CKD mice (Mazumder et al. 2019) Furthermore, the study reported reduction of neuronal arborization in hippocampus and loss of dendritic spines in the cortex and hippocampus. CKD mice had increased superoxide dismutase activity and decreased catalase activity (markers of oxidative stress) in the cortex and hippocampus. The study also showed mitochondrial dysfunction and increase in reactive glial cells (indicator of inflammation). Increase of inflammation and oxidative stress can be an explanation for reduced acetylcholinesterase activity, loss of dendritic arborization and spines, and cognitive decline observed in these mice (Mazumder et al. 2019).

\section{Structural brain changes and imaging methods}

CKD can affect brain structure on many levels and the morphologic alterations can be both acute and chronic. The most valuable method to assess the cerebral changes is magnetic resonance imaging (MRI). However, imaging modality of choice in the acute setting is computed tomography (CT). The advantages of CT include shorter scanning time, better availability and lower cost.

Freedman et al. 2017, performed MRI structural analysis of the brain in the early stages of CKD caused by type 2 diabetes mellitus. The mildly higher urine albumin-creatine ratio and lower eGFR correlated with decreased gray matter (GM) volume. White matter (WM) lesions volume were increased, which was associated with the cerebral microvascular disease. The CKD patients had poorer digit symbol coding performance. These findings suggest that the structural brain changes begin in the early stages of the CKD and affect cognition. Several other studies associated reduced kidney function with smaller GM volume (Tsuruya and Yoshida 2018) and higher WM disease burden (Sink et al. 2015, Tamura et al. 2016, Khatri et al. 2007). Decreased GM volume (in bilateral medial orbito-prefrontal cortex, left middle temporal gyrus, left dorsal lateral prefrontal cortex and right dorsal lateral prefrontal cortex) of the ESRD patients was related to the functional brain deficits. Regions with GM volume reduction had altered functional connectivity with other brain regions (Qiu et al. 2014).

Tract based spatial statistics of the diffusion tensor imaging (an advanced MRI technique) has allowed visualization of the structural interconnectivity of the WM tracts by measurement of anisotropic diffusion of water. ESRD patients had lower fractional anisotropy and increased mean (Drew et al. 2017, Kong et al. 2014) and radial diffusivity (Zhang et al. 2015, Chou et al. 2013, Yin et al. 2018). These findings can be interpreted as the loss of the WM integrity, demyelination and diffuse interstitial brain edema.

Silent brain infarction (SBI) (Fig. 2) is characterized as a cerebral infarction detected by imaging method, but without clinical correlate. Shima et. al. (2011) reported SBI in $31.8 \%$ of predialysis CKD patients. Their typical localization is in the deep brain structures (Kobayashi et al. 2009, Kobayashi et al. 2004, Shima et al. 2011). Likewise, the prevalence of the brain microhemorrhages (Fig. 2) is higher among CKD population (Vemuri et al. 2017). These are presumably 
caused by structural abnormalities of the small vessels and are typically found infratentorially and in the deep brain regions (Ovbiagele et al. 2013, Peng et al. 2016). Both cerebral microbleeds and silent brain infarction are associated with increased risk of stroke and their incidence rises with the progression of the CKD. (Akoudad et al. 2015, Kobayashi et al. 2009, Shima et al. 2011, Shima et al. 2016).

Xiao et al. investigated the relationship between chronic kidney disease and enlarged perivascular spaces (Fig. 2) using the FLAIR MRI sequence. As the eGFR decreased, the severity of the enlarged perivascular spaces increased together with the cerebral small vessel disease (Xiao et al. 2015).
In summary, it is possible to detect cerebral structural changes from the early stages of the CKD, both in the GM and the WM. Brain abnormalities and cognitive deficit progress with the severity of the CKD and are most expressed among hemodialyzed patients (Pi et al. 2016). The neurocognitive decline is most likely a result of the WM damage (Fig. 2), reflecting small vessel disease (Vogels et al. 2012, Wada et al. 2008, Knopman et al. 2008). Integrity of WM tract, structural and functional connectivity of brain networks and cognitive performance can improve after renal transplantation (Gupta et al. 2016, Findlay et al. 2019, Chen et al. 2020, Joshee et al. 2018).
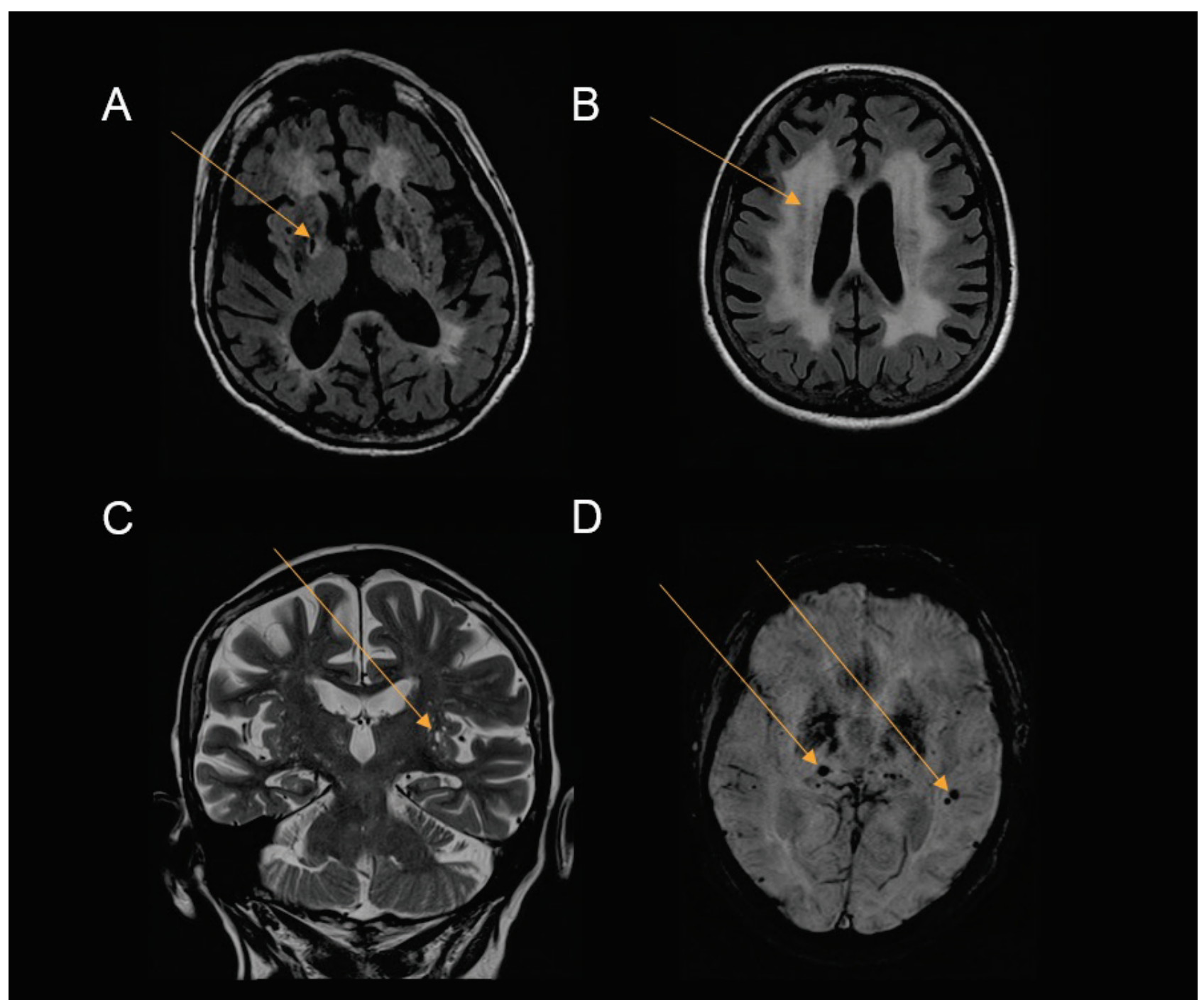

Fig. 2. Structural brain changes Source: Department of Radiology, Faculty hospital Kralovske Vinohrady (Images are only an illustration of the common pathologies among CKD patients) A) FLAIR T2WI MRI, chronic lacunar infarction - low intensity lesion with hyperintense rim of gliosis in the right lobe (basal ganglia) B) FLAIR T2WI MRI, degeneration and gliosis of the white matter appear as extensive periventricular hyperintense lesions C) T2WI MRI, enlarged perivascular spaces D) SWI MRI, cerebral microbleeds - small areas of signal loss 


\section{Conclusions}

Structural and functional brain changes can be observed since the early stages of CKD and the executive functions are affected first. The cognitive decline has progressive character, can eventually lead to dementia and is positively correlated with renal functions. The presence of ESRD and the hemodialysis therapy itself have detrimental effects on the brain, probably stronger than the general risk factors (Etgen et al. 2012).

Increased levels of pro-inflammatory cytokines, increased oxidative stress and other traditional and nontraditional vascular risk factors (which can be accented in CKD) accelerate CNS damage through vascular endothelial dysfunction. Findings on imaging methods confirm this hypothesis. The hallmark of CKD is degeneration and damage of WM, thus findings typical for vascular dementia. The BBB dysfunction can be the starting point of the WM lesions (Huang et al. 2018).

Increased levels of some uremic toxins have neurotoxic and/or gliotoxic effect and can contribute to brain damage. Other factors, known from the general population, such as education level, depression, psychiatric diseases, sleep disturbances, polypharmacy, malnutrition and superimposed neurodegenerative diseases could also alter cognitive functions of these patients.

\section{Conflict of Interest}

There is no conflict of interest.

\section{Acknowledgements}

This review has been supported by the grant of the Agency of Health Research of the Czech Republic [17-31796A].

\section{Abbreviations}

ADMA, Asymmetric dimethylarginine; BBB, Blood brain barrier; $\mathrm{CBF}$, Cerebral blood flow; CKD, Chronic kidney disease; $\mathrm{CMRO}_{2}$, Cerebral metabolic rate of oxygen; CNS, Central nervous system; $\mathrm{crSO}_{2}$, Cerebral oxygenation; CT, Computed tomography; DSM-5, Diagnostic and statistical manual of mental disorders; eGFR, Estimated glomerular filtration rate; GM, Gray matter; ESRD, End stage renal disease; HD, Hemodialysis; MCI, Mild cognitive impairment; MRI, Magnetic resonance imaging; NIRS, Near-infrared spectroscopy; PD, Peritoneal dialysis; $\mathrm{rSO}_{2}$, Regional oxygen saturation; SBI, Silent brain infarction; WM, White matter

\section{References}

ADESSO S, MAGNUS T, CUZZOCREA S, CAMPOLO M, RISSIEK B, PACIELLO O, AUTORE G, PINTO A, MARZOCCO S: Indoxyl sulfate affects glial function increasing oxidative stress and neuroinflammation in chronic kidney disease: interaction between astrocytes and microglia. Front Pharmacol 8: 370, 2017. https://doi.org/10.3389/fphar.2017.00370

AKOUDAD S, PORTEGIES ML, KOUDSTAAL PJ, HOFMAN A, VAN DER LUGT A, IKRAM MA, VERNOOIJ MW: Cerebral microbleeds are associated with an increased risk of stroke: The Rotterdam study. Circulation 132: 509-516, 2015. https://doi.org/10.1161/CIRCULATIONAHA.115.016261

ARNOLD R, ISSAR T, KRISHNAN AV, PUSSELL BA: Neurological complications in chronic kidney disease. JRSM Cardiovasc Dis 5: 2048004016677687, 2016. https://doi.org/10.1177/2048004016677687

ASSOCIATION AP: Diagnostic and statistical manual of mental disorders (DSM-5®). 2013.

BROUNS R, DE DEYN PP: Neurological complications in renal failure: a review. Clin Neurol Neurosurg 107: 1-16, 2004. https://doi.org/10.1016/j.clineuro.2004.07.012

BRUCK K, STEL VS, GAMBARO G, HALLAN S, VOLZKE H, ARNLOV J, KASTARINEN M, GUESSOUS I, VINHAS J, STENGEL B, BRENNER H, CHUDEK J, ROMUNDSTAD S, TOMSON C, GONZALEZ AO, BELLO AK, FERRIERES J, PALMIERI L, BROWNE G, CAPUANO V, VAN BIESEN W, ZOCCALI C, GANSEVOORT R, NAVIS G, ROTHENBACHER D, FERRARO PM, NITSCH D, WANNER C, JAGER KJ, EUROPEAN CKDBC: CKD prevalence varies across the European general population. J Am Soc Nephrol 27: 2135-2147, 2016. https://doi.org/10.1681/ASN.2015050542

BUGNICOURT JM, GODEFROY O, CHILLON JM, CHOUKROUN G, MASSY ZA: Cognitive disorders and dementia in CKD: the neglected kidney-brain axis. J Am Soc Nephrol 24: 353-363, 2013. https://doi.org/10.1681/ASN.2012050536 
CATCHLOVE SJ, MACPHERSON H, HUGHES ME, CHEN Y, PARRISH TB, PIPINGAS A: An investigation of cerebral oxygen utilization, blood flow and cognition in healthy aging. PLoS One 13: e0197055, 2018. https://doi.org/10.1371/journal.pone.0197055

CHEN HJ, WANG YF, WEN J, XU Q, LU GM, ZHANG LJ: Functional-structural relationship in large-scale brain networks of patients with end stage renal disease after kidney transplantation: A longitudinal study. Hum Brain Mapp 41: 328-341, 2020. https://doi.org/10.1002/hbm.24804

CHEN JJ, ROSAS HD, SALAT DH: Age-associated reductions in cerebral blood flow are independent from regional atrophy. Neuroimage 55: 468-478, 2011. https://doi.org/10.1016/j.neuroimage.2010.12.032

CHENG BC, CHEN PC, CHEN PC, LU CH, HUANG YC, CHOU KH, LI SH, LIN AN, LIN WC: Decreased cerebral blood flow and improved cognitive function in patients with end-stage renal disease after peritoneal dialysis: An arterial spin-labelling study. Eur Radiol 29: 1415-1424, 2019. https://doi.org/10.1007/s00330-018-5675-9

CHOU MC, HSIEH TJ, LIN YL, HSIEH YT, LI WZ, CHANG JM, KO CH, KAO EF, JAW TS, LIU GC: Widespread white matter alterations in patients with end-stage renal disease: a voxelwise diffusion tensor imaging study. AJNR Am J Neuroradiol 34: 1945-1951, 2013. https://doi.org/10.3174/ajnr.A3511

DANEMAN R, PRAT A: The blood-brain barrier. Cold Spring Harb Perspect Biol 7: a020412, 2015. https://doi.org/10.1101/cshperspect.a020412

DE DEYN PP, D'HOOGE R, VAN BOGAERT PP, MARESCAU B: Endogenous guanidino compounds as uremic neurotoxins. Kidney Int Suppl 78: S77-83, 2001. https://doi.org/10.1046/j.1523-1755.59.s78.51.x

DEGUCHI T, ISOZAKI K, YOUSUKE K, TERASAKI T, OTAGIRI M: Involvement of organic anion transporters in the efflux of uremic toxins across the blood-brain barrier. J Neurochem 96: 1051-1059, 2006. https://doi.org/10.1111/j.1471-4159.2005.03550.x

DOBRIAN AD: ADMA and NOS regulation in chronic renal disease: beyond the old rivalry for l-arginine. Kidney Int 81: 722-724, 2012. https://doi.org/10.1038/ki.2011.496

DREW DA, KOO BB, BHADELIA R, WEINER DE, DUNCAN S, LA GARZA MM, GUPTA A, TIGHIOUART H, SCOTT T, SARNAK MJ: White matter damage in maintenance hemodialysis patients: a diffusion tensor imaging study. BMC Nephrol 18: 213, 2017. https://doi.org/10.1186/s12882-017-0628-0

ELIAS MF, DORE GA, DAVEY A: Kidney disease and cognitive function. Contrib Nephrol 179: 42-57, 2013. https://doi.org/10.1159/000346722

ENGELHARDT B, LIEBNER S: Novel insights into the development and maintenance of the blood-brain barrier. Cell Tissue Res 355: 687-699, 2014. https://doi.org/10.1007/s00441-014-1811-2

ETGEN T, CHONCHOL M, FORSTL H, SANDER D: Chronic kidney disease and cognitive impairment: a systematic review and meta-analysis. Am J Nephrol 35: 474-482, 2012. https://doi.org/10.1159/000338135

FINDLAY MD, DAWSON J, DICKIE DA, FORBES KP, MCGLYNN D, QUINN T, MARK PB: Investigating the relationship between cerebral blood flow and cognitive function in hemodialysis patients. J Am Soc Nephrol 30: 147-158, 2019. https://doi.org/10.1681/ASN.2018050462

FRATIGLIONI L, QIU C: Prevention of cognitive decline in ageing: dementia as the target, delayed onset as the goal. Lancet Neurol 10: 778-779, 2011. https://doi.org/10.1016/S1474-4422(11)70145-4

FREEDMAN BI, SINK KM, HUGENSCHMIDT CE, HUGHES TM, WILLIAMSON JD, WHITLOW CT, PALMER ND, MILLER ME, LOVATO LC, XU J, SMITH SC, LAUNER LJ, BARZILAY JI, COHEN RM, SULLIVAN MD, BRYAN RN, WAGNER BC, BOWDEN DW, MALDJIAN JA, DIVERS J, AA-DHS M, INVESTIGATORS AM: Associations of early kidney disease with brain magnetic resonance imaging and cognitive function in african americans with type 2 diabetes mellitus. Am J Kidney Dis 70: 627-637, 2017. https://doi.org/10.1053/j.ajkd.2017.05.006

GESUALDO GD, DUARTE JG, ZAZZETTA MS, KUSUMOTA L, SAY KG, PAVARINI SCI, ORLANDI FS: Cognitive impairment of patients with chronic renal disease on hemodialysis and its relationship with sociodemographic and clinical characteristics. Dement Neuropsychol 11: 221-226, 2017. https://doi.org/10.1590/1980-57642016dn11-030003

GRIVA K, STYGALL J, HANKINS M, DAVENPORT A, HARRISON M, NEWMAN SP: Cognitive impairment and 7-year mortality in dialysis patients. Am J Kidney Dis 56: 693-703, 2010. https://doi.org/10.1053/j.ajkd.2010.07.003 
GUILLEMIN GJ: Quinolinic acid, the inescapable neurotoxin. FEBS J 279: 1356-1365, 2012. https://doi.org/10.1111/j.1742-4658.2012.08485.x

GUPTA A, LEPPING RJ, YU AS, PEREA RD, HONEA RA, JOHNSON DK, BROOKS WM, BURNS JM: Cognitive function and white matter changes associated with renal transplantation. Am J Nephrol 43: 50-57, 2016. https://doi.org/10.1159/000444334

HALLMANN R, HORN N, SELG M, WENDLER O, PAUSCH F, SOROKIN LM: Expression and function of laminins in the embryonic and mature vasculature. Physiol Rev 85: 979-1000, 2005. https://doi.org/10.1152/physrev.00014.2004

HILL NR, FATOBA ST, OKE JL, HIRST JA, O'CALLAGHAN CA, LASSERSON DS, HOBBS FD: Global prevalence of chronic kidney disease - a systematic review and meta-analysis. PLoS One 11: e0158765, 2016. https://doi.org/10.1371/journal.pone.0158765

HIRAKATA H, YAO H, OSATO S, IBAYASHI S, ONOYAMA K, OTSUKA M, ICHIYA Y, KUWABARA Y, MASUDA Y, FUJISHIMA M: CBF and oxygen metabolism in hemodialysis patients: effects of anemia correction with recombinant human EPO. Am J Physiol 262: F737-743, 1992. https://doi.org/10.1152/ajprenal.1992.262.5.F737

HOSHINO T, OOKAWARA S, GOTO S, MIYAZAWA H, ITO K, UEDA Y, KAKU Y, HIRAI K, NABATA A, MORI H, YOSHIDA I, TABEI K: Evaluation of cerebral oxygenation in patients undergoing long-term hemodialysis. Nephron Clin Pract 126: 57-61, 2014. https://doi.org/10.1159/000358432

HOSOYA K, TACHIKAWA M: Roles of organic anion/cation transporters at the blood-brain and blood-cerebrospinal fluid barriers involving uremic toxins. Clin Exp Nephrol 15: 478-485, 2011. https://doi.org/10.1007/s10157011-0460-y

HUANG J, LI J, FENG C, HUANG X, WONG L, LIU X, NIE Z, XI G: Blood-brain barrier damage as the starting point of leukoaraiosis caused by cerebral chronic hypoperfusion and its involved mechanisms: effect of agrin and aquaporin-4. Biomed Res Int 2018: 2321797, 2018. https://doi.org/10.1155/2018/2321797

HUGO J, GANGULI M: Dementia and cognitive impairment: epidemiology, diagnosis, and treatment. Clin Geriatr Med 30: 421-442, 2014. https://doi.org/10.1016/j.cger.2014.04.001

IADECOLA C: The neurovascular unit coming of age: a journey through neurovascular coupling in health and disease. Neuron 96: 17-42, 2017. https://doi.org/10.1016/j.neuron.2017.07.030

ITO K, OOKAWARA S, UEDA Y, GOTO S, MIYAZAWA H, YAMADA H, KITANO T, SHINDO M, KAKU Y, HIRAI K, YOSHIDA M, HOSHINO T, NABATA A, MORI H, YOSHIDA I, KAKEI M, TABEI K: Factors affecting cerebral oxygenation in hemodialysis patients: cerebral oxygenation associates with $\mathrm{pH}$, hemodialysis duration, serum albumin concentration, and diabetes mellitus. PLoS One 10: e0117474, 2015. https://doi.org/10.1371/journal.pone.0117474

IYASERE O, OKAI D, BROWN E: Cognitive function and advanced kidney disease: longitudinal trends and impact on decision-making. Clin Kidney J 10: 89-94, 2017. https://doi.org/10.1093/ckj/sfw128

JABBARI B, VAZIRI ND: The nature, consequences, and management of neurological disorders in chronic kidney disease. Hemodial Int 22: 150-160, 2018. https://doi.org/10.1111/hdi.12587

JHA V, GARCIA-GARCIA G, ISEKI K, LI Z, NAICKER S, PLATTNER B, SARAN R, WANG AY, YANG CW: Chronic kidney disease: global dimension and perspectives. Lancet 382: 260-272, 2013. https://doi.org/10.1016/S0140-6736(13)60687-X

JIANG XL, WEN JQ, ZHANG LJ, ZHENG G, LI X, ZHANG Z, LIU Y, ZHENG LJ, WU L, CHEN HJ, KONG X, LUO S, LU GM, JI XM, ZHANG ZJ: Cerebral blood flow changes in hemodialysis and peritoneal dialysis patients: an arterial-spin labeling MR imaging. Metab Brain Dis 31: 929-936, 2016. https://doi.org/10.1007/s11011-016-9829-7

JIN M WL, WANG H, HAN X, DIAO Z, GUO W, YANG Z, DING H, WANG Z, ZHANG P, ZHAO P, LV H, LIU W, WANG Z: Disturbed neurovascular coupling in hemodialysis patients. PeerJ 8:e8989, 2020. https://doi.org/10.7717/peerj.8989

JING W, JABBARI B, VAZIRI ND: Uremia induces upregulation of cerebral tissue oxidative/inflammatory cascade, down-regulation of Nrf2 pathway and disruption of blood brain barrier. Am J Transl Res 10: 2137-2147, 2018. 
JOSHEE P, WOOD AG, WOOD ER, GRUNFELD EA: Meta-analysis of cognitive functioning in patients following kidney transplantation. Nephrol Dial Transplant 33: 1268-1277, 2018. https://doi.org/10.1093/ndt/gfx240

KEANEY J, CAMPBELL M: The dynamic blood-brain barrier. FEBS J 282: 4067-4079, 2015. https://doi.org/10.1111/febs.13412

KHATRI M, WRIGHT CB, NICKOLAS TL, YOSHITA M, PAIK MC, KRANWINKEL G, SACCO RL, DECARLI C: Chronic kidney disease is associated with white matter hyperintensity volume: the Northern Manhattan Study (NOMAS). Stroke 38: 3121-3126, 2007. https://doi.org/10.1161/STROKEAHA.107.493593

KNOPMAN DS, MOSLEY TH, JR., BAILEY KR, JACK CR JR., SCHWARTZ GL, TURNER ST: Associations of microalbuminuria with brain atrophy and white matter hyperintensities in hypertensive sibships. J Neurol Sci 271: 53-60, 2008. https://doi.org/10.1016/j.jns.2008.03.009

KOBAYASHI M, HIRAWA N, YATSU K, KOBAYASHI Y, YAMAMOTO Y, SAKA S, ANDOH D, TOYA Y, YASUDA G, UMEMURA S: Relationship between silent brain infarction and chronic kidney disease. Nephrol Dial Transplant 24: 201-207, 2009. https://doi.org/10.1093/ndt/gfn419

KOBAYASHI S, IKEDA T, MORIYA H, OHTAKE T, KUMAGAI H: Asymptomatic cerebral lacunae in patients with chronic kidney disease. Am J Kidney Dis 44: 35-41, 2004. https://doi.org/10.1053/j.ajkd.2004.03.026

KONG X, WEN JQ, QI RF, LUO S, ZHONG JH, CHEN HJ, JI GJ, LU GM, ZHANG LJ: Diffuse interstitial brain edema in patients with end-stage renal disease undergoing hemodialysis: a tract-based spatial statistics study. Medicine (Baltimore) 93: e313, 2014. https://doi.org/10.1097/MD.0000000000000313

KONTOS HA, RAPER AJ, PATTERSON JL: Analysis of vasoactivity of local $\mathrm{pH}, \mathrm{PCO}_{2}$ and bicarbonate on pial vessels. Stroke 8: 358-360, 1977. https://doi.org/10.1161/01.STR.8.3.358

KRISHNAN AV, KIERNAN MC: Neurological complications of chronic kidney disease. Nat Rev Neurol 5: 542-551, 2009. https://doi.org/10.1038/nrneurol.2009.138

LAMEIRE N, VANHOLDER R, DE SMET R: Uremic toxins and peritoneal dialysis. Kidney Int Suppl 78: S292-297, 2001. https://doi.org/10.1046/j.1523-1755.2001.07820.x

LASSEN NA: Normal average value of cerebral blood flow in younger adults is $50 \mathrm{ml} / 100 \mathrm{~g} / \mathrm{min}$. J Cereb Blood Flow Metab 5: 347-349, 1985. https://doi.org/10.1038/jcbfm.1985.48

LAU WL, NUNES ACF, VASILEVKO V, FLORIOLLI D, LERTPANIT L, SAVOJ J, BANGASH M, YAO Z, SHAH K, NAQVI S, PAGANINI-HILL A, VAZIRI ND, CRIBBS DH, FISHER M: Chronic kidney disease increases cerebral microbleeds in mouse and man. Transl Stroke Res 11: 122-134, 2020. https://doi.org/10.1007/s12975019-00698-8

LEE CT, KUO CC, CHEN YM, HSU CY, LEE WC, TSAI YC, NG HY, KUO LC, CHIOU TT, YANG YK, CHENG BC, CHEN JB: Factors associated with blood concentrations of indoxyl sulfate and p-cresol in patients undergoing peritoneal dialysis. Perit Dial Int 30: 456-463, 2010a. https://doi.org/10.3747/pdi.2009.00092

LEE MC, TING KK, ADAMS S, BREW BJ, CHUNG R, GUILLEMIN GJ: Characterisation of the expression of NMDA receptors in human astrocytes. PLoS One 5: e14123, 2010b. https://doi.org/10.1371/journal.pone.0014123

LEENDERS KL, PERANI D, LAMMERTSMA AA, HEATHER JD, BUCKINGHAM P, HEALY MJ, GIBBS JM, WISE RJ, HATAZAWA J, HEROLD S, et al.: Cerebral blood flow, blood volume and oxygen utilization. Normal values and effect of age. Brain 113 (Pt 1): 27-47, 1990. https://doi.org/10.1093/brain/113.1.27

LIN YT, WU PH, LEE HH, MUBANGA M, CHEN CS, KUO MC, CHIU YW, KUO PL, HWANG SJ: Indole-3 acetic acid increased risk of impaired cognitive function in patients receiving hemodialysis. Neurotoxicology 73 : 85-91, 2019. https://doi.org/10.1016/j.neuro.2019.02.019

LISOWSKA-MYJAK B: Uremic toxins and their effects on multiple organ systems. Nephron Clin Pract 128: 303-311, 2014. https://doi.org/10.1159/000369817

LIU CY, YANG Y, JU WN, WANG X, ZHANG HL: Emerging roles of astrocytes in neuro-vascular unit and the tripartite synapse with emphasis on reactive gliosis in the context of Alzheimer's disease. Front Cell Neurosci 12: 193, 2018a. https://doi.org/10.3389/fncel.2018.00193

LIU HS, HARTUNG EA, JAWAD AF, WARE JB, LANEY N, PORT AM, GUR RC, HOOPER SR, RADCLIFFE J, FURTH SL, DETRE JA: Regional cerebral blood flow in children and young adults with chronic kidney disease. Radiology 288: 849-858, 2018b. https://doi.org/10.1148/radiol.2018171339 
LIU S, AGALLIU D, YU C, FISHER M: The role of pericytes in blood-brain barrier function and stroke. Curr Pharm Des 18: 3653-3662, 2012. https://doi.org/10.2174/138161212802002706

LIU WC, TOMINO Y, LU KC: Impacts of indoxyl sulfate and p-cresol sulfate on chronic kidney disease and mitigating effects of AST-120. Toxins (Basel) 10: 2018c. https://doi.org/10.3390/toxins10090367

MACEWEN C, SUTHERLAND S, DALY J, PUGH C, TARASSENKO L: Relationship between hypotension and cerebral ischemia during hemodialysis. J Am Soc Nephrol 28: 2511-2520, 2017. https://doi.org/10.1681/ASN.2016060704

MALIK J: Heart disease in chronic kidney disease - review of the mechanisms and the role of dialysis access. J Vasc Access 19: 3-11, 2018. https://doi.org/10.5301/jva.5000815

MALIK J, KUDLICKA J, LACHMANOVA J, VALERIANOVA A, ROCINOVA K, BARTKOVA M, TESAR V: Tissue ischemia worsens during hemodialysis in end-stage renal disease patients. J Vasc Access no. 10.5301/jva.50006300, 2016. https://doi.org/10.5301/jva.5000630

MALKIEWICZ MA, SZARMACH A, SABISZ A, CUBALA WJ, SZUROWSKA E, WINKLEWSKI PJ: Blood-brain barrier permeability and physical exercise. J Neuroinflammation 16: 15, 2019. https://doi.org/10.1186/s12974019-1403-X

MALYSZKO J: Mechanism of endothelial dysfunction in chronic kidney disease. Clin Chim Acta 411: 1412-1420, 2010. https://doi.org/10.1016/j.cca.2010.06.019

MANSOUR A, RASHAD S, NIIZUMA K, FUJIMURA M, TOMINAGA T: A novel model of cerebral hyperperfusion with blood-brain barrier breakdown, white matter injury, and cognitive dysfunction. J Neurosurg no. 10.3171/2019.7.JNS192121-13, 2019. https://doi.org/10.3171/2019.7.JNS19212

MARZOCCO S, POPOLO A, BIANCO G, PINTO A, AUTORE G: Pro-apoptotic effect of methylguanidine on hydrogen peroxide-treated rat glioma cell line. Neurochem Int 57: 518-524, 2010. https://doi.org/10.1016/j.neuint.2010.06.016

MASSON P, WEBSTER AC, HONG M, TURNER R, LINDLEY RI, CRAIG JC: Chronic kidney disease and the risk of stroke: a systematic review and meta-analysis. Nephrol Dial Transplant 30: 1162-1169, 2015. https://doi.org/10.1093/ndt/gfv009

MATHEW RJ, RABIN P, STONE WJ, WILSON WH: Regional cerebral blood flow in dialysis encephalopathy and primary degenerative dementia. Kidney Int 28: 64-68, 1985. https://doi.org/10.1038/ki.1985.119

MAZUMDER MK, PAUL R, BHATTACHARYA P, BORAH A: Neurological sequel of chronic kidney disease: From diminished Acetylcholinesterase activity to mitochondrial dysfunctions, oxidative stress and inflammation in mice brain. Sci Rep 9: 3097, 2019. https://doi.org/10.1038/s41598-018-37935-3

MCQUILLAN R, JASSAL SV: Neuropsychiatric complications of chronic kidney disease. Nat Rev Nephrol 6: 471-479, 2010. https://doi.org/10.1038/nrneph.2010.83

MEYER TW, HOSTETTER TH: Approaches to uremia. J Am Soc Nephrol 25: 2151-2158, 2014. https://doi.org/10.1681/ASN.2013121264

MOERMAN A, WOUTERS P: Near-infrared spectroscopy (NIRS) monitoring in contemporary anesthesia and critical care. Acta Anaesthesiol Belg 61: 185-194, 2010.

MURRAY AM: Cognitive impairment in the aging dialysis and chronic kidney disease populations: an occult burden. Adv Chronic Kidney Dis 15: 123-132, 2008. https://doi.org/10.1053/j.ackd.2008.01.010

MURRAY AM, TUPPER DE, KNOPMAN DS, GILBERTSON DT, PEDERSON SL, LI S, SMITH GE, HOCHHALTER AK, COLLINS AJ, KANE RL: Cognitive impairment in hemodialysis patients is common. Neurology 67: 216-223, 2006. https://doi.org/10.1212/01.wnl.0000225182.15532.40

NAYAK-RAO S, SHENOY MP: Stroke in patients with chronic kidney disease...: How do we approach and manage it? Indian J Nephrol 27: 167-171, 2017. https://doi.org/10.4103/0971-4065.202405

NETTO JP, ILIFF J, STANIMIROVIC D, KROHN KA, HAMILTON B, VARALLYAY C, GAHRAMANOV S, DALDRUP-LINK H, D'ESTERRE C, ZLOKOVIC B, SAIR H, LEE Y, TAHERI S, JAIN R, PANIGRAHY A, REICH DS, DREWES LR, CASTILLO M, NEUWELT EA: Neurovascular unit: basic and clinical imaging with emphasis on advantages of ferumoxytol. Neurosurgery 82: 770-780, 2018. https://doi.org/10.1093/neuros/nyx357 
OBERMEIER B, DANEMAN R, RANSOHOFF RM: Development, maintenance and disruption of the blood-brain barrier. Nat Med 19: 1584-1596, 2013. https://doi.org/10.1038/nm.3407

OHTSUKI S, ASABA H, TAKANAGA H, DEGUCHI T, HOSOYA K, OTAGIRI M, TERASAKI T: Role of bloodbrain barrier organic anion transporter 3 (OAT3) in the efflux of indoxyl sulfate, a uremic toxin: its involvement in neurotransmitter metabolite clearance from the brain. J Neurochem 83: 57-66, 2002. https://doi.org/10.1046/j.1471-4159.2002.01108.x

OLIVA-DAMASO E, OLIVA-DAMASO N, RODRIGUEZ-ESPARRAGON F, PAYAN J, BAAMONDE-LABORDA E, GONZALEZ-CABRERA F, SANTANA-ESTUPINAN R, RODRIGUEZ-PEREZ JC: Asymmetric (ADMA) and Symmetric (SDMA) Dimethylarginines in chronic kidney disease: a clinical approach. Int J Mol Sci 20: 2019. https://doi.org/10.3390/ijms20153668

OVBIAGELE B, WING JJ, MENON RS, BURGESS RE, GIBBONS MC, SOBOTKA I, GERMAN L, SHARA NM, FERNANDEZ S, JAYAM-TROUTH A, EDWARDS DF, KIDWELL CS: Association of chronic kidney disease with cerebral microbleeds in patients with primary intracerebral hemorrhage. Stroke 44: 2409-2413, 2013. https://doi.org/10.1161/STROKEAHA.113.001958

PALMER AM: The role of the blood-CNS barrier in CNS disorders and their treatment. Neurobiol Dis 37: 3-12, 2010. https://doi.org/10.1016/j.nbd.2009.07.029

PAPADOPOULOS G, DOUNOUSI E, PAPATHANASIOU A, PAPATHANAKOS G, TZIMAS P: Cerebral oximetry values in dialyzed surgical patients: a comparison between hemodialysis and peritoneal dialysis. Ren Fail 35: 855-859, 2013. https://doi.org/10.3109/0886022X.2013.794675

PENG Q, SUN W, LIU W, LIU R, HUANG Y, GROUP CS: Longitudinal relationship between chronic kidney disease and distribution of cerebral microbleeds in patients with ischemic stroke. J Neurol Sci 362: 1-6, 2016. https://doi.org/10.1016/j.jns.2016.01.015

PHAM NM, RECHT NS, HOSTETTER TH, MEYER TW: Removal of the protein-bound solutes indican and p-cresol sulfate by peritoneal dialysis. Clin J Am Soc Nephrol 3: 85-90, 2008. https://doi.org/10.2215/CJN.02570607

PI HC, XU YF, XU R, YANG ZK, QU Z, CHEN YQ, LIU GL, DONG J: Cognitive impairment and structural neuroimaging abnormalities among patients with chronic kidney disease. Kidney Blood Press Res 41: 986-996, 2016. https://doi.org/10.1159/000452603

POLINDER-BOS HA, GARCIA DV, KUIPERS J, ELTING JWJ, ARIES MJH, KRIJNEN WP, GROEN H, WILLEMSEN ATM, VAN LAAR PJ, STRIJKERT F, LUURTSEMA G, SLART R, WESTERHUIS R, GANSEVOORT RT, GAILLARD C, FRANSSEN CFM: hemodialysis induces an acute decline in cerebral blood flow in elderly patients. J Am Soc Nephrol 29: 1317-1325, 2018. https://doi.org/10.1681/ASN.2017101088

PROHOVNIK I, POST J, URIBARRI J, LEE H, SANDU O, LANGHOFF E: Cerebrovascular effects of hemodialysis in chronic kidney disease. J Cereb Blood Flow Metab 27: 1861-1869, 2007. https://doi.org/10.1038/sj.jcbfm.9600478

QIU Y, LV X, SU H, JIANG G, LI C, TIAN J: Structural and functional brain alterations in end stage renal disease patients on routine hemodialysis: a voxel-based morphometry and resting state functional connectivity study. PLoS One 9: e98346, 2014. https://doi.org/10.1371/journal.pone.0098346

REINECKE H, BRAND E, MESTERS R, SCHABITZ WR, FISHER M, PAVENSTADT H, BREITHARDT G: Dilemmas in the management of atrial fibrillation in chronic kidney disease. J Am Soc Nephrol 20: 705-711, 2009. https://doi.org/10.1681/ASN.2007111207

SEDAGHAT S, VERNOOIJ MW, LOEHRER E, MATTACE-RASO FU, HOFMAN A, VAN DER LUGT A, FRANCO OH, DEHGHAN A, IKRAM MA: Kidney function and cerebral blood flow: the Rotterdam Study. J Am Soc Nephrol 27: 715-721, 2016. https://doi.org/10.1681/ASN.2014111118

SETIADI A, KORIM WS, ELSAAFIEN K, YAO ST: The role of the blood-brain barrier in hypertension. Exp Physiol 103: 337-342, 2018. https://doi.org/10.1113/EP086434

SHARIF Y, JUMAH F, COPLAN L, KROSSER A, SHARIF K, TUBBS RS: Blood brain barrier: A review of its anatomy and physiology in health and disease. Clin Anat 31: 812-823, 2018. https://doi.org/10.1002/ca.23083 
SHIMA H, ISHIMURA E, NAGANUMA T, ICHII M, YAMASAKI T, MORI K, NAKATANI T, INABA M: Decreased kidney function is a significant factor associated with silent cerebral infarction and periventricular hyperintensities. Kidney Blood Press Res 34: 430-438, 2011. https://doi.org/10.1159/000328722

SHIMA H, MORI T, OOI M, SONODA M, SHOJI T, ISHIMURA E, OKAMURA M, ISHIZAKA N, INABA M: Silent cerebral microbleeds and longitudinal risk of renal and cardiovascular events in patients with CKD. Clin J Am Soc Nephrol 11: 1557-1565, 2016. https://doi.org/10.2215/CJN.13481215

SINK KM, DIVERS J, WHITLOW CT, PALMER ND, SMITH SC, XU J, HUGENSCHMIDT CE, WAGNER BC, WILLIAMSON JD, BOWDEN DW, MALDJIAN JA, FREEDMAN BI: Cerebral structural changes in diabetic kidney disease: African American-Diabetes Heart Study MIND. Diabetes Care 38: 206-212, 2015. https://doi.org/10.2337/dc14-1231

STAMATOVIC SM, KEEP RF, ANDJELKOVIC AV: Brain endothelial cell-cell junctions: how to "open" the blood brain barrier. Curr Neuropharmacol 6: 179-192, 2008. https://doi.org/10.2174/157015908785777210

STUBBS JR, HOUSE JA, OCQUE AJ, ZHANG S, JOHNSON C, KIMBER C, SCHMIDT K, GUPTA A, WETMORE JB, NOLIN TD, SPERTUS JA, YU AS: Serum trimethylamine-n-oxide is elevated in CKD and correlates with

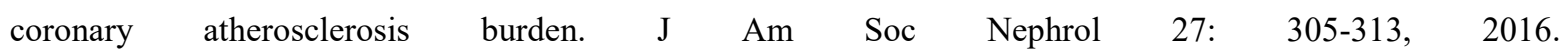
https://doi.org/10.1681/ASN.2014111063

TAMURA MK, PAJEWSKI NM, BRYAN RN, WEINER DE, DIAMOND M, VAN BUREN P, TAYLOR A, BEDDHU S, ROSENDORFF C, JAHANIAN H, ZAHARCHUK G, GROUP SSR: Chronic kidney disease, cerebral blood flow, and white matter volume in hypertensive adults. Neurology 86: 1208-1216, 2016. https://doi.org/10.1212/WNL.0000000000002527

TAMURA MK, YAFFE K: Dementia and cognitive impairment in ESRD: diagnostic and therapeutic strategies. Kidney Int 79: 14-22, 2011. https://doi.org/10.1038/ki.2010.336

TARUMI T, ZHANG R: Cerebral blood flow in normal aging adults: cardiovascular determinants, clinical implications, and aerobic fitness. J Neurochem 144: 595-608, 2018. https://doi.org/10.1111/jnc.14234

TASKER RC: Brain vascular and hydrodynamic physiology. Semin Pediatr Surg 22: 168-173, 2013. https://doi.org/10.1053/j.sempedsurg.2013.10.003

TING KK, BREW BJ, GUILLEMIN GJ: Effect of quinolinic acid on human astrocytes morphology and functions: implications in Alzheimer's disease. J Neuroinflammation 6: 36, 2009. https://doi.org/10.1186/1742-2094-6-36

TRIPATHI M, VIBHA D: Reversible dementias. Indian J Psychiatry 51 (Suppl 1): S52-S55, 2009.

TSURUYA K, YOSHIDA H: Brain atrophy and cognitive impairment in chronic kidney disease. Contrib Nephrol 196: 27-36, 2018. https://doi.org/10.1159/000485694

UENO M, TOMIMOTO H, AKIGUCHI I, WAKITA H, SAKAMOTO H: Blood-brain barrier disruption in white matter lesions in a rat model of chronic cerebral hypoperfusion. J Cereb Blood Flow Metab 22: 97-104, 2002. https://doi.org/10.1097/00004647-200201000-00012

VALERIANOVA A, LACHMANOVA J, KOVAROVA L, KMENTOVA T, BARTKOVA M, MALIK J: Factors responsible for cerebral hypoxia in hemodialysis population. Physiol Res 68: 651-658, 2019. https://doi.org/10.33549/physiolres.934064

VAN SANDWIJK MS, TEN BERGE IJ, MAJOIE CB, CAAN MW, DE SONNEVILLE LM, VAN GOOL WA, BEMELMAN FJ: Cognitive changes in chronic kidney disease and after transplantation. Transplantation 100: 734-742, 2016. https://doi.org/10.1097/TP.0000000000000968

VANHOLDER R, MEERT N, VAN BIESEN W, MEYER T, HOSTETTER T, DHONDT A, ELOOT S: Why do patients on peritoneal dialysis have low blood levels of protein-bound solutes? Nat Clin Pract Nephrol 5: 130-131, 2009. https://doi.org/10.1038/ncpneph1023

VANHOLDER RC, GLORIEUX G, DE SMET R, DE DEYN PP: Low water-soluble uremic toxins. Adv Ren Replace Ther 10: 257-269, 2003. https://doi.org/10.1053/j.arrt.2003.08.003

VARATHARAJ A, GALEA I: The blood-brain barrier in systemic inflammation. Brain Behav Immun 60: 1-12, 2017. https://doi.org/10.1016/j.bbi.2016.03.010

VAVILALA MS, LEE LA, LAM AM: Cerebral blood flow and vascular physiology. Anesthesiol Clin North Am 20: 247-264, v, 2002. https://doi.org/10.1016/S0889-8537(01)00012-8 
VEMURI P, KNOPMAN DS, JACK CR, JR., LUNDT ES, WEIGAND SD, ZUK SM, THOSTENSON KB, REID RI, KANTARCI K, SLININ Y, LAKSHMINARAYAN K, DAVEY CS, MURRAY A: Association of kidney function biomarkers with brain MRI findings: The BRINK Study. J Alzheimers Dis 55: 1069-1082, 2017. https://doi.org/10.3233/JAD-160834

VIGGIANO D, WAGNER CA, BLANKESTIJN PJ, BRUCHFELD A, FLISER D, FOUQUE D, FRISCHE S, GESUALDO L, GUTIERREZ E, GOUMENOS D, HOORN EJ, ECKARDT KU, KNAUSS S, KONIG M, MALYSZKO J, MASSY Z, NITSCH D, PESCE F, RYCHLIK I, SOLER MJ, SPASOVSKI G, STEVENS KI, TREPICCIONE F, WANNER C, WIECEK A, ZOCCALI C, UNWIN R, CAPASSO G: Mild cognitive impairment and kidney disease: clinical aspects. Nephrol Dial Transplant 35: 10-17, 2020. https://doi.org/10.1093/ndt/gfz051

VOGELS SC, EMMELOT-VONK MH, VERHAAR HJ, KOEK HL: The association of chronic kidney disease with brain lesions on MRI or CT: a systematic review. Maturitas 71: 331-336, 2012. https://doi.org/10.1016/j.maturitas.2012.01.008

VORSTRUP S, LASS P, WALDEMAR G, BRANDI L, SCHMIDT JF, JOHNSEN A, PAULSON OB: Increased cerebral blood flow in anemic patients on long-term hemodialytic treatment. J Cereb Blood Flow Metab 12: 745-749, 1992. https://doi.org/10.1038/jcbfm.1992.105

WADA M, NAGASAWA H, ISEKI C, TAKAHASHI Y, SATO H, ARAWAKA S, KAWANAMI T, KURITA K, DAIMON M, KATO T: Cerebral small vessel disease and chronic kidney disease (CKD): results of a crosssectional study in community-based Japanese elderly. J Neurol Sci 272: 36-42, 2008. https://doi.org/10.1016/j.jns.2008.04.029

WAGNER M, JURCOANE A, VOLZ S, MAGERKURTH J, ZANELLA FE, NEUMANN-HAEFELIN T, DEICHMANN R, SINGER OC, HATTINGEN E: Age-related changes of cerebral autoregulation: new insights with quantitative T2'-mapping and pulsed arterial spin-labeling MR imaging. AJNR Am J Neuroradiol 33: 2081-2087, 2012. https://doi.org/10.3174/ajnr.A3138

WEBSTER AC, NAGLER EV, MORTON RL, MASSON P: Chronic kidney disease. Lancet 389: 1238-1252, 2017. https://doi.org/10.1016/S0140-6736(16)32064-5

WILLIAMS LR, LEGGETT RW: Reference values for resting blood flow to organs of man. Clin Phys Physiol Meas 10: 187-217, 1989. https://doi.org/10.1088/0143-0815/10/3/001

XIAO L, LAN W, SUN W, DAI Q, XIONG Y, LI L, ZHOU Y, ZHENG P, FAN W, MA N, GUO Z, CHEN X, XIE X, XU L, ZHU W, XU G, LIU X: Chronic kidney disease in patients with lacunar stroke: association with enlarged perivascular spaces and total magnetic resonance imaging burden of cerebral small vessel disease. Stroke 46: 2081-2086, 2015. https://doi.org/10.1161/STROKEAHA.114.008155

YASUI-FURUKORI N, TARAKITA N, UEMATSU W, SAITO H, NAKAMURA K, OHYAMA C, SUGAWARA N: Delirium in hemodialysis predicts mortality: a single-center, long-term observational study. Neuropsychiatr Dis Treat 13: 3011-3016, 2017. https://doi.org/10.2147/NDT.S152355

YIN Y, LI M, LI C, MA X, YAN J, WANG T, FU S, HUA K, WU Y, ZHAN W, JIANG G: Reduced white matter integrity with cognitive impairments in end stage renal disease. Front Psychiatry 9: 143, 2018. https://doi.org/10.3389/fpsyt.2018.00143

ZEPEDA-OROZCO D, QUIGLEY R: Dialysis disequilibrium syndrome. Pediatr Nephrol 27: 2205-2211, 2012. https://doi.org/10.1007/s00467-012-2199-4

ZHANG R, LIU K, YANG L, ZHOU T, QIAN S, LI B, PENG Z, LI M, SANG S, JIANG Q, SUN G: Reduced white matter integrity and cognitive deficits in maintenance hemodialysis ESRD patients: a diffusion-tensor study. Eur Radiol 25: 661-668, 2015. https://doi.org/10.1007/s00330-014-3466-5

ZOCCALI C, BENEDETTO FA, MAAS R, MALLAMACI F, TRIPEPI G, MALATINO LS, BOGER R, INVESTIGATORS C: Asymmetric dimethylarginine, C-reactive protein, and carotid intima-media thickness in end-stage renal disease. J Am Soc Nephrol 13: 490-496, 2002. 